\title{
Perceptions of Farmers in Bangladesh to Asian Elephants (Elephas maximus)
}

\author{
A. H. M. Raihan Sarker ${ }^{1} \&$ Eivin Røskaft ${ }^{2}$ \\ ${ }^{1}$ Institute of Forestry and Environmental Sciences, University of Chittagong, Chittagong, Bangladesh \\ ${ }^{2}$ Department of Biology, Norwegian University of Science and Technology (NTNU), Norway \\ Correspondence: Eivin Røskaft, Department of Biology, Norwegian University of Science and Technology \\ (NTNU), Realfagbygget, Trondheim No-7491, Norway. Tel: 47-9065-2883. E-mail: roskaft@bio.ntnu.no
}

\author{
Received: March 5, 2014 Accepted: April 7, 2014 Online Published: May 22, 2014 \\ doi:10.5539/enrr.v4n2p23 URL: http://dx.doi.org/10.5539/enrr.v4n2p23
}

\begin{abstract}
We explored the degree to which Bangladeshi farmers perceive Asian elephants (Elephas maximus) as agricultural pests, as related to the type of farming and other demographic profile of the farmers. We analysed the size and cropping patterns of farms raided by wild elephants, the extent and nature of crop loss, the months and crop-raiding time; and the size of elephants' herds that caused crop-raiding incidents. The average loss of entire crops increased with distance from the park up to $300 \mathrm{~m}$ and then decreased with greater the distance. The greatest loss due to crop raiding was associated with specific crops. Farmers incurred the greatest mean losses in terms of cost from like rice, vegetables, banana, and teak. The highest proportion of small losses occurred during the early evening, while the greatest financial losses occurred during late evening. Wild elephants raided crops throughout most of the year, but the greatest loss and cost were incurred during the monsoon season. The proportion of crops lost varied with the herd size of elephant responsible for crop-raiding and the duration of crop-raiding. Differences were found in the views of farmers regarding the perceptions towards elephant as pest. Considering crop-raiding elephant herd as pest has been given different views by the farmers based on their financial/comfortable status.
\end{abstract}

Keywords: agricultural pests, Asian elephants, crop raiding, compensation, demographic factor, small-scale farmers, large-scale farmers, socio-economic factors

\section{Introduction}

The largest conflicts and the greatest losses between humans and wildlife occur in villages bordering parks (Naughton-Treves, 1998), indicating that the borders of park are the crucial point of the conflict (Hart \& O'Connell, 1998). The human-wildlife conflicts, which may involve injury or death of livestock and human as well as crop damage incurred the major costs of living closer to protected area (Gillingham \& Lee, 2003; Roe \& Elliott, 2006). The usual defence of killing problem animals is confined by conservation policy in and around protected areas and farmers are not compensated in most of cases for crop losses caused by wild animals (Laudati, 2010; Naughton-Treves, 1997) due to lack of financial support to run compensation schemes (Tchamba, 1996). However, allocation of funds to run compensation schemes are needed to explore mitigation measures, which again can be used to reduce the intensity of crop raiding (Sitati \& Walpole, 2006; Warren, Buba, \& Ross, 2007). Farmers usually guard their crops by shouting, using chili ropes, trenches, or dogs that are useful in some cases against crop raiders (Sitati, Walpole, \& Leader-Williams, 2005), although guarding of agricultural fields usually restrict farmers from alternative income generating activities (Osborn \& Parker, 2003). Thus, people residing at park edges often require protection or compensation from the Forest Department; if they do not receive it, they may retaliate by killing the problem wildlife in protest, ultimately causing serious population declines. Such protests can undermine conservation initiatives regionally or nationally (Hart \& O'Connell, 1998; Naughton-Treves, 1998; Tchamba, 1996; Tweheyo, Hill, \& Obua, 2005).

The cost of conflict between human and wildlife exposes people's unenthusiastic feelings towards the management of protected areas. The situation is worsened by the fact that people resent the protection of these damaging animals. When people resides around protected areas, they complain that wild animals intrude their agricultural fields (Laudati, 2010). On the other hand, protected areas authorities argue that both local people and immigrants have encroached habitats of wild animals due to a severe human population growth (Sitati, Walpole, 
\& Leader-Williams, 2005). Farmers are unable to protect their crops when they live close to protected areas. For instances, in Africa nearly $17 \%$ of crop loss occurred by insects, birds, and small mammals, by disease (15.6\%), and by weeds (16.6\%) (Oerke, Dehne, Schonbeck, \& Weber, 1994). In Tanzania and Uganda, farmers reported that park-protected animals caused crop raiding in their settlement zone (Weber, Hill, \& Reynolds, 2007). Mackenzie and Ahabyona (2012) reported that in Kibale National Park, Uganda, the farmers incurred the cost of crop-loss on an average US\$ 74 due to crop-raiding over six months and the intensity of crop loss was higher within 500 meters from the park boundary. Consequently, farmers who lived next to protected areas killed animals or provided support to poachers (Nyhus, Tilson, \& Sumianto, 2000; Sifuna, 2005). Therefore, human-wildlife conflict is a subject of intense attention to conservation biologists (Dixon \& Sherman, 1990; Dublin \& Hoare, 2004; Dudley, Mensah-Ntiamoah, \& Kpelle, 1992; Tchamba, 1996).

Land use with integrating approach is particularly not easy where densely settled agricultural land adjoins a protected area holding large and potentially dangerous animals like Asian elephant, Elephas maximus (Sarker \& Røskaft, 2011b; Sukumar, 1991). The advent of agriculture approximately 10,000 years ago introduced a new dimension to the interaction between elephants and people. Farmed crops attracted the elephants' attention as sources of food, and elephant-human conflicts increased over this resource as well as over territory as permanent settlements and agriculture gradually spread throughout the elephants' habitats (Barnes, 1996). Concurrently, increasing human use of the natural landscape for firewood, foods and fodder for livestock, significantly affects the elephants' habitat and, consequently, the elephant population. Habitat degradation, fragmentation and the disruption of the traditional migratory routes of elephants due to human activities increased the level of conflict between human and elephant and reduced the geographical range of the elephants, resulting in more frequent contact with humans (Røskaft, Larsen, Mojaphoko, Sarker, \& Jackson, 2014; Sarker, 2010). Marked differences exist in the beliefs of nature enthusiasts and villagers living near park surrounding the value of conserving wildlife in protected areas (Infield, 1988). The conservationist groups argue that for ecological aspects the existing elephant population should be sustained in protected areas, whereas the people residing around protected areas argue that wild elephants are major threats to their livelihoods. Such disputes may have negative impacts on conservation strategies (Gillingham, 1998). In Mozambique, farmers who received cost of crop damage caused by African elephants (Loxodonta africana) exposed more negative attitudes towards the Maputo Elephant Reserve than those who had not (de Boer \& Baquete, 1998). Despite increasing crop damage by elephants around park areas, uncertainty persists about the extent of such problems in Bangladesh (Khan, Khan, \& Biswas, 2004). Local people who live closer to protected areas in many parts of the world rank crop raiding by wild elephants as the largest problem (de Boer \& Baquete, 1998; Gillingham \& Lee, 1999; Hill, 1997; Lee \& Priston, 2005; Naughton-Treves, 1997).

Elephants are in conflict with humans in almost all of their ranges in Bangladesh (Sarker \& Røskaft, 2010), and crop depredation by elephants is the most common cause of such conflicts (Sarker \& Røskaft, 2011a). Crop damage caused by wild elephants occurs mainly in the transition zones between farms and elephant habitats (Sukumar, 1989). The level of crop damage is generally low in and around protected areas, where farms are small, while crop damage is particularly high in those areas where the landscape is overlapping human-use areas and elephant habitats (Bandara \& Tisdell, 2002). Moreover, small pockets of elephant habitat are associated with severe crop raiding, especially when the remaining habitat is insufficient to support these large herbivores (Sarker \& Røskaft, 2010). Thus, the management of the human-elephant conflict has become a topic of national, regional and international significance.

Farmers are not likely to tolerate crop loss without grievance. In fact, farmers often exaggerate the degree of crop damage by wild elephants and other wildlife (Daniel, 1996; Sarker \& Røskaft, 2010). Farmers are likely to regard the Asian elephant as a dangerous agricultural pest (Bandara \& Tisdell, 2002), yet elephants are a conservation priority, partly due to their use and non-use economic values. Wild elephants instigate antagonism and fear among those who intrude on and occupy their natural habitats (Sarker \& Røskaft, 2011b). The animosity of farmers towards Asian elephants has been highlighted in several studies (Aung, 1997; Nyhus, Tilson, \& Sumianto, 2000; Ramakrishnan, Sivaganesan, \& Srivatava, 1997; Tisdell \& Xiang, 1998), and Kotagama (1997) notes that while elephants are often blamed for crop damage, although rodents or primates, cause much greater crop losses over time. Therefore, it is confusing to understand whether the wild elephant is a pest or a resource (Bandara \& Tisdell, 2002).

Despite increasing crop damage by elephants around protected areas, indecision perseveres about the definite extent of this dilemma in Bangladesh (Sarker \& Røskaft, 2010). Farmers' bitter complaints imprison the notice of protected area managers, but only rarely are the real impacts of different wildlife species recorded or are the predictors of crop damage evaluated (Sarker \& Røskaft, 2010). Moreover, farmers-elephants interactions have 
received amazingly little consideration from researchers conducting quantitative analyses (Allaway, 1979). The absence of actual crop damage caused by wild elephants hampers successful management, precise assessments of sites, and formulation of cost-effective policy and act. The high variability in crop damage caused by wild elephants and the inadequacy of databases hamper efforts to address this politically charged and controversial issue.

Most of the published research on crop damage by wildlife around protected areas is based on interviews with farmers (Hill, 1998; Newmark, Manyanza, Gamassa, \& Sariko, 1994). These studies reveal human perceptions of the risks of crop loss but do not account for interview-introduced erroneousness. At several sites, findings of studies have revealed a disparity between reported and observed crop damage by wildlife, finding that farmers generally overestimate the amount of the cost of crop loss caused by wildlife (Mwathe, 1992). Moreover, errors are often introduced by extrapolating observations from a single site to an entire park or reserve; by focusing on sites where crop raiding is most intense, damage may be overestimated (Bell, 1984).

Inadequate attention to the elephants' habitat requirements by those engaged in development activities near elephant habitats in Bangladesh can increase in order to lessen the severity of crop raiding (Sarker \& Røskaft, 2010). The major objective of this study is to explore the quantitative aspects of elephant pest problems. The nature and degree of the crop damage and the economic loss caused by wild elephants are examined in the context of several crop-raiding incidents recorded in the South-Eastern and Northern parts of Bangladesh. Our hypothesis is that crop-raiding incidents and farmers' perceptions of wild elephants as an agricultural pest vary considerably with farm distances from the park boundary and the costs incurred from crop raiding.

\section{Methods}

\subsection{Study Area}

We worked in four IUCN-protected areas of Bangladesh (IUCN, 1994): the Teknaf Game Reserve, TGR (Category VI); the Chunati Wildlife Sanctuary, CWS (Category V); a forest reserve adjacent to the Dulahazara Safari Park in the South-East of Bangladesh, RF 2 (Category 1b); and a forest reserve that lies between the political border of Bangladesh and India, RF 1 (Category 1b) (Figure 1).

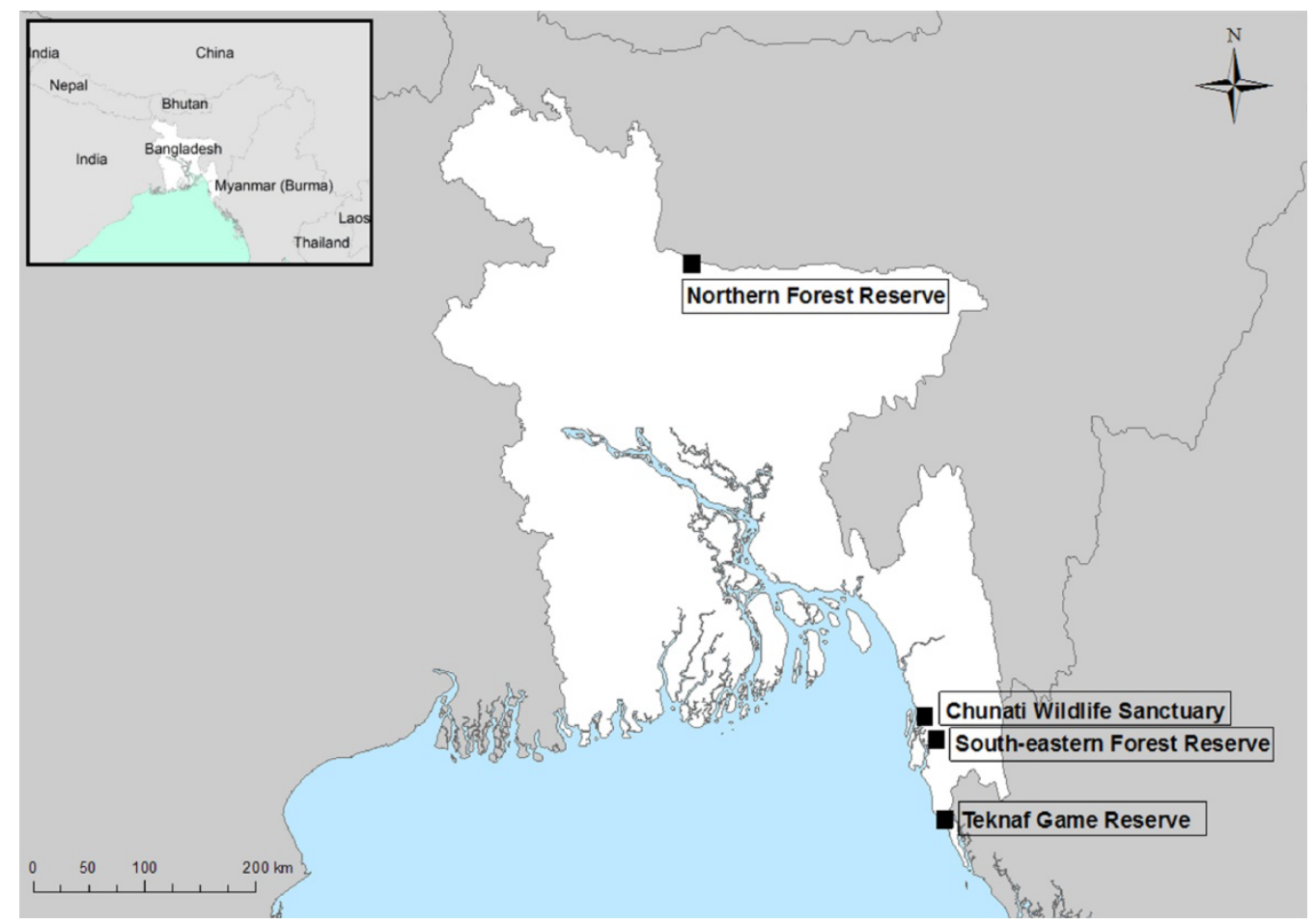

Figure 1. Map showing the location of the four protected areas studied in Bangladesh

The Teknaf Game Reserve is situated approximately $48 \mathrm{~km}$ south of Cox’s Bazar district $\left(21^{\circ} 04^{\prime} \mathrm{N}, 9^{\circ} 09^{\prime} \mathrm{E}\right)$, comprising $116.15 \mathrm{~km}^{2}$ and covering 10 blocks (i.e., Raikhong, Saplapur, Shilkhali, Maddyanilla, Dakhin-Nilla, 
Matabhanga, Rajachara, Ledha, Dumdumia and Teknaf) in three forest ranges (Whykong, Silkhali and Teknaf) of Cox's Bazar South Forest Division. The game reserve is charged with managing and protecting wildlife in addition to increasing the populations of important wildlife species, especially wild elephants. Within this reserve, the capture of wildlife is illegal. The reserve was established in 1983 as a game reserve under the Wildlife Preservation Act (1974), and it is located near the political border between Bangladesh and Myanmar. The current designation of game reserve does not provide adequate protection for the elephant habitats. Therefore, the re-designation of the area as a wildlife sanctuary was intended to provide a greater scope for protection. The game reserve comprises a linear hill range, gently sloping to rugged hills and cliffs running down the central part of the peninsula, with a North-South length of nearly $28 \mathrm{~km}$ and an East-West width of 3-5 km. A number of deep gullies and narrow valleys are crossed by numerous streams flowing down to the Naf River in the East and the Bay of Bengal in the West. Rainfall mainly occurs between May and October. During the study period (July 2008 to June 2009), the mean annual precipitation was $451 \mathrm{~mm}$ and the mean annual temperature was $26.5{ }^{\circ} \mathrm{C}$, ranging from $21.7{ }^{\circ} \mathrm{C}$ to $30.3{ }^{\circ} \mathrm{C}$. According to the population census (1991), the household and human population densities around the game reserve area were 60.9 per $\mathrm{km}^{2}$ and 392.5 per $\mathrm{km}^{2}$, respectively (BBS, 2009).

The Chunati Wildlife Sanctuary is situated approximately $70 \mathrm{~km}$ South of the city of Chittagong on the west side of Chittagong-Cox's Bazar Highway $\left(21^{\circ} 58^{\prime} \mathrm{N}, 92^{\circ} 04^{\prime} \mathrm{E}\right)$ and encompasses parts of the Banskhali and Lohagara sub-districts of the Chittagong District and the Chokoria Upazila of Cox's Bazar District. The sanctuary was established in 1986 under the Chittagong South Forest Division, but it has recently been transferred to the newly created Wildlife and Nature Conservation Division of the Forest Department. Administratively, the sanctuary is divided into two forest ranges (i.e., Jaldi and Chunati) and 7 forest blocks. The sanctuary was formally established through a gazette notification under the provision of the Wildlife Preservation Act (1974). It covers an area of $77.64 \mathrm{~km}^{2}$ and was designated by the government as an undisturbed breeding ground for the protection of wildlife (primarily) with natural resources. Numerous clear creeks with gravelly and stony beds traverse the area. During the study period, the mean annual temperature of the sanctuary area was $26.6^{\circ} \mathrm{C}$, ranging from $21.8^{\circ} \mathrm{C}$ to $31.4^{\circ} \mathrm{C}$, and the average annual rainfall was $390 \mathrm{~mm}$. The population census (1991) showed that the household density and the human population density around the wildlife sanctuary were 131.3 per $\mathrm{km}^{2}$ and 785.9 per $\mathrm{km}^{2}$, respectively (BBS, 2009).

The reserve forest surrounded by the Fasiakhali Range of the Cox's Bazar North Forest Division $\left(21^{\circ} 40^{\prime} \mathrm{N}\right.$ and $92^{\circ} 04^{\prime} \mathrm{E}$ ), was established in 1897 and is approximately $27.1 \mathrm{~km}^{2}$ in area. The altitude is approximately $9 \mathrm{~m}$ above the mean sea level. The topography of this reserve is characterised as an undulating hilly area. Low hills of this area are less than $100 \mathrm{~m}$ in elevation, and approximately $15 \%$ of the landscape is inundated during the rainy season. The mean annual rainfall and temperature were $264.3 \mathrm{~mm}$ and $26.2^{\circ} \mathrm{C}$ (ranging from $22.5^{\circ} \mathrm{C}$ to $29.9^{\circ} \mathrm{C}$ ), respectively, during the period from July 2008 to June 2009 . Some narrow valleys retain moisture throughout the year, and perennial natural streams flow inside the reserve and form shallow water pools. The household and human population densities around the reserve area were 118.4 per $\mathrm{km}^{2}$ and 753.1 per $\mathrm{km}^{2}$, respectively (BBS, 2009).

The reserve forest around the Bangladesh-India border at the Assam-Meghalaya region passes through the Kangsha, Dhansail, Rangtia and Fakirabad unions of the Jhenaigati $\left(25^{\circ} 16^{\prime} \mathrm{N}\right.$ and $\left.90^{\circ} 01^{\prime} \mathrm{E}\right)$ and the Nayabill union of the Nalitabari sub-district $\left(25^{\circ} 13^{\prime} \mathrm{N}\right.$ and $\left.90^{\circ} 08^{\prime} \mathrm{E}\right)$ of the Sherpur district. The forest area comprises approximately $5 \mathrm{~km}^{2}$ of scattered forest as a reserve forest. The area of the reserve forest is predominantly a secondary Sal forest. The average annual rainfall during the study period was $252.7 \mathrm{~mm}$, and the mean annual temperature was $26.6^{\circ} \mathrm{C}$, ranging from $22.3{ }^{\circ} \mathrm{C}$ to $30.9^{\circ} \mathrm{C}$. The household density and the human population density around the reserve area were 130.3 per $\mathrm{km}^{2}$ and 685.3 per km² , respectively (BBS, 2009).

\subsection{Sampling and Data Collection}

We carried out fieldwork from July 2008 to June 2009, recording 46 incidents of crop raiding by wild elephants for quantitative analysis, of which 33 incidents occurred in both agricultural farms and home gardens, and the remaining 11 incidents were observed only in agricultural farms. We collected data using a questionnaire to understand the aspects of elephant crop raiding in the study areas. One person from each village ( $\mathrm{N}=99$ villages) was selected to tell us about the presence of elephants in the village. We considered the following criteria for the selection of an informant: 1) the person must reside within $0.5 \mathrm{~km}$ of the park boundary, and 2) he or she must be able to inform the field assistants of the presence of elephants by mobile phone.

After receiving a message from the informant, we investigated the farms raided by wild elephants. The extent of crop damage caused by the elephants was assessed in relation to two major farm types (agricultural farms and 
home gardens) and farms were located within $0.5 \mathrm{~km}$ of the boundary of the park. An agricultural farm is a tract of land cultivated for agricultural production, while home gardens are forest gardens, where farmers cultivate trees and horticultural crops on the same land. In Bangladesh, home gardens are the most common form of land use and combine different fruit species. In this study, however, we defined both agricultural farms and home gardens as "farms". We categorised the cropping patterns as "agricultural crops" (i.e., rice, vegetables, and betel leaf), "horticultural crops" (i.e., fruit trees) and "forest crops" (i.e., bamboo, teak, and mahogany) for analysis. In this study, we only interviewed farmers $(\mathrm{N}=44)$ whose farms were raided by wild elephants. The interview questionnaire included questions about socio-economic and demographic variables and one question related to the perception of farmers towards the elephants as a pest. The socio-economic and demographic variables were related to the distance of the farm from the park border $(<100 \mathrm{~m}, 101-200 \mathrm{~m}, 201-300 \mathrm{~m}$, and $>300 \mathrm{~m})$, the amount of crop loss and associated cost from crop-raiding by wild elephants, investment for production and protection of crops, settlement status (residential, immigrant, or hired from other places), education (none, primary education and above), age, household size, occupation (small-scale farmers, medium-scale farmers, and large-scale farmers) based on farm size, and monthly income of respondents. Then, for analyses, we classified the respondents as "small-scale farmers" or "large-scale farmers" according to the size of the farm they owned. All farms below the average farm size (i.e., $10901 \mathrm{~m}^{2}$ ) were considered "small farms", all others were classified as "large farms" and we defined both small- and large-scale farmers as "farmers". We also categorised the farmers into residents (born locally) and immigrants; poor [average monthly income less than Taka (Tk) 5443 or equivalent US\$ 78] and rich (more than Tk 5443 per month); illiterate (no education or never went to school) and literate (completed at least primary level school education). The distance of each farm from the park boundary was estimated using GPS (Global Positioning System). We recorded the amount of damage by counting damaged stems or fruits of planted crops (e.g., jackfruit, banana, coconut, papaya, mango, blackberry, bamboo, teak, and mahogany) and converting the damage into local currency (i.e., Tk) using the average market price for each crop. Damage to sown crops (e.g., rice, vegetables, and betel leaf) was measured directly in square metre $\left(\mathrm{m}^{2}\right)$. We then estimated the amount of crop loss per square metre in local currency. We categorised the crop loss in local currency as a "small loss" or a "high loss" based on the average loss (i.e., Tk 14206). Any loss below the average loss was considered a "small loss", losses above the average were classified as a "high loss". We recorded the investment in farm development and the cost of raiding deterrents for each farm raided by elephants to calculate the total investment cost. In addition, we recorded data on timing and the month of crop raiding and the size of the raiding elephant's herd. Finally, we asked each farmer $(\mathrm{N}=44)$ the following question: "Have you considered the wild elephant as an agricultural pest on your farm?" (no / yes / don't know ).

\subsection{Data Analyses}

Data were analysed using SPSS v. 16.0 (SPSS, Chicago, USA). Differences in costs of crop losses across protected areas and farmer's perceptions were explored using one-way ANOVA and chi-square $\left(\chi^{2}\right)$ tests. The relationships between attitudes and socio-economic and demographic variables were explored with multivariate statistics. A stepwise logistic regression was used to analyse relationships among multiple variables with responses to the above pest question as the dependent variable.

\section{Results}

\subsection{Socio-Economic and Demographic Analyses}

The major socio-economic and demographic characteristics of the farmers showed statistically significant variation among the four protected areas (Table 1). More than half of the farmers had farms $>200 \mathrm{~m}$ from the park. Most farmers were residents, illiterate, large-scale farmers, and rich. All small-scale farmers were illiterate $(100 \%)$, while the illiteracy rate among the large-scale farmers was approximately $12.0 \%\left(\chi^{2}=35.4, \mathrm{df}=1, \mathrm{P}<\right.$ 0.0001 ). The mean age and the mean family size of the farmers was $41.9 \pm 9.1$ (SD) years and $8.2 \pm 2.5$ (SD) persons per family. 
Table 1. Demographic and socio-economic data, obtained from interviews of farmers whose farms were raided by wild elephants in the vicinity of the protected areas included in the study, and $\chi^{2}$ tests of independence between the four study areas

\begin{tabular}{|c|c|c|c|c|c|c|c|c|c|}
\hline \multicolumn{2}{|c|}{ Demographic factors } & \multirow{2}{*}{$\begin{array}{c}\begin{array}{c}\mathrm{CWS} \\
(\mathrm{N}=13)\end{array} \\
30.8\end{array}$} & \multirow{2}{*}{$\begin{array}{c}\begin{array}{c}\text { TGR } \\
(\mathrm{N}=15)\end{array} \\
46.7\end{array}$} & \multirow{2}{*}{$\begin{array}{c}\begin{array}{c}\mathrm{RF} 2 \\
(\mathrm{~N}=11)\end{array} \\
36.4\end{array}$} & \multirow{2}{*}{$\begin{array}{l}\text { RF 1 } \\
(\mathrm{N}=7)\end{array}$} & \multirow{2}{*}{$\begin{array}{c}\begin{array}{c}\text { Total } \\
(\mathrm{N}=46)\end{array} \\
47.8\end{array}$} & \multirow[t]{2}{*}{$\chi^{2}$} & \multirow[t]{2}{*}{$\mathrm{df}$} & \multirow[t]{2}{*}{$\mathrm{p}$} \\
\hline Distance of farm & $<200 \mathrm{~m}(\%)$ & & & & & & & & \\
\hline from park & $>200 \mathrm{~m}(\%)$ & 69.2 & 53.3 & 63.6 & 0.0 & 52.2 & 9.7 & 3 & 0.021 \\
\hline \multirow{2}{*}{ Settlement status } & Residents (\%) & 69.2 & 73.3 & 45.5 & 0.0 & 54.3 & & & \\
\hline & Immigrant (\%) & 30.8 & 26.7 & 54.5 & 100.0 & 45.7 & 12.0 & 3 & 0.007 \\
\hline \multirow{2}{*}{ Education } & Illiterate $(\%)$ & 38.5 & 60.0 & 27.3 & 100.0 & 52.2 & & & \\
\hline & Literate $(\%)$ & 61.5 & 40.0 & 72.7 & 0.0 & 47.8 & 10.5 & 3 & 0.015 \\
\hline \multirow{2}{*}{ Occupation } & Small farmers $(\%)$ & 30.8 & 46.7 & 27.3 & 100.0 & 45.7 & & & \\
\hline & Large farmers $(\%)$ & 69.2 & 53.3 & 72.7 & 0.0 & 54.3 & 10.9 & 3 & 0.012 \\
\hline \multirow{2}{*}{ Financial status } & Poor $(\%)$ & 30.8 & 53.3 & 27.3 & 100.0 & 47.8 & & & \\
\hline & Rich (\%) & 69.2 & 46.7 & 72.7 & 0.0 & 52.2 & 11.2 & 3 & 0.011 \\
\hline
\end{tabular}

Note: CWS = Chunati Wildlife Sanctuary; TGR = Teknaf Game Reserve; RF 2 = Forest Reserve in south-eastern Bangladesh; RF 1 = Forest Reserve in northern Bangladesh.

\subsection{Farm Size}

Farm size varied considerably across the study sites (Table 2a). The average farm was larger in South-East Bangladesh (CWS, RF 2, and TGR) than in northern Bangladesh (RF 1).

Table 2a. Farm size in relation to the degree of protection in each of the protected areas and the distance of the farm from the park boundary (see Table 1 for the elaboration of protected areas), and ANOVA-tests of differences between the four areas

\begin{tabular}{|c|c|c|c|c|c|c|c|c|}
\hline Farm & CWS & TGR & RF 2 & RF 1 & Total & $\mathrm{F}$ & $\mathrm{df}$ & $\mathrm{p}$ \\
\hline $\begin{array}{l}\text { Agriculture }\left(\mathrm{m}^{2}\right) \\
\qquad(\mathrm{N}=46)\end{array}$ & $\begin{array}{c}11000.8 \pm 3294.8 \\
(\mathrm{~N}=13)\end{array}$ & $\begin{array}{c}9568.5 \pm 4093.9 \\
(\mathrm{~N}=15)\end{array}$ & $\begin{array}{c}10814.6 \pm \\
4352.0(\mathrm{~N}=11)\end{array}$ & $\begin{array}{c}4015.4 \pm \\
574.3(\mathrm{~N}=7)\end{array}$ & $\begin{array}{c}9426.22 \pm \\
4255.59(\mathrm{~N}=46)\end{array}$ & 6.5 & 3 & 0.001 \\
\hline $\begin{array}{l}\text { Home garden } \\
\left(\mathrm{m}^{2}\right)(\mathrm{N}=33)\end{array}$ & $\begin{array}{c}2342.8 \pm 399.9 \\
(\mathrm{~N}=9)\end{array}$ & $\begin{array}{c}2132.2 \pm 600.9 \\
(\mathrm{~N}=10)\end{array}$ & $\begin{array}{c}2266.3 \pm 673.8 \\
(\mathrm{~N}=9)\end{array}$ & $\begin{array}{c}1005.6 \pm \\
511.1(\mathrm{~N}=5)\end{array}$ & $\begin{array}{c}2055.52 \pm 705.32 \\
(\mathrm{~N}=33)\end{array}$ & 7.0 & 3 & 0.001 \\
\hline
\end{tabular}

Note: All values are mean \pm SD.

Farm size also varied considerably with the distance of the farm from the park boundary. On average, farms were smaller closer to the park boundary but increased in size farther from the protected areas (Table 2b).

Table $2 b$. Farm size in relation to the distance of the farm from the park boundary (see Table 1 for the elaboration of protected areas), and ANOVA-tests of differences between the four areas

\begin{tabular}{|c|c|c|c|c|c|c|c|c|}
\hline Distance from park & $<100 \mathrm{~m}$ & $101-200 \mathrm{~m}$ & $201-300 \mathrm{~m}$ & $>300 \mathrm{~m}$ & Total & $\mathrm{F}$ & df & $\mathrm{p}$ \\
\hline $\begin{array}{l}\text { Agriculture }\left(\mathrm{m}^{2}\right) \\
\quad(\mathrm{N}=46)\end{array}$ & $\begin{array}{c}3552.8 \pm \\
567.4(\mathrm{~N}=9)\end{array}$ & $\begin{array}{c}7232.8 \pm \\
1989.8(\mathrm{~N}=13)\end{array}$ & $\begin{array}{c}11800.3 \pm \\
1496.1(\mathrm{~N}=18)\end{array}$ & $\begin{array}{c}15866.3 \pm \\
835.6(\mathrm{~N}=6)\end{array}$ & $\begin{array}{c}9426.22 \pm \\
4255.95(\mathrm{~N}=46)\end{array}$ & 110.5 & 3 & 0.0001 \\
\hline $\begin{array}{l}\text { Home garden }\left(\mathrm{m}^{2}\right) \\
\qquad(\mathrm{N}=33)\end{array}$ & $\begin{array}{c}698.0 \pm \\
141.4(\mathrm{~N}=2)\end{array}$ & $\begin{array}{c}1239.1 \pm 529.4 \\
(\mathrm{~N}=7)\end{array}$ & $\begin{array}{c}2241.8 \pm 226.6 \\
\quad(\mathrm{~N}=18)\end{array}$ & $\begin{array}{c}2901.7 \pm \\
121.6(\mathrm{~N}=6)\end{array}$ & $\begin{array}{c}2055.52 \pm \\
705.32(\mathrm{~N}=33)\end{array}$ & 48.5 & 3 & 0.0001 \\
\hline
\end{tabular}

Note: All values are mean \pm SD. 


\subsection{Cropping Patterns}

In total, 12 different crops were recorded in farms across the study areas (Table 3). These crops included rice (Oryza sativa), a variety of local vegetables, betel leaf (Piper betle), different types of fruits, and timber species. In the agricultural farms, rice and vegetables were common. The home garden consisted of perennial and semi-perennial crops, including jackfruit (Artocarpus integrifolia), banana (Musa paradisiaca), and coconut (Cocos nucifera). In addition, papaya (Carica papaya), mango (Mangifera indica), blackberry (Rubus fruticosus) , bamboo (Bambusa vulgaris), teak (Tectona grandis), and mahogany (Swietenia mahagoni) were planted in home gardens. Rice and vegetables were the major agricultural crops cultivated across all study areas. Among the horticultural species, jackfruit, banana, and coconut were the major fruit species cultivated. Bamboo was cultivated on the largest scale (compared to teak and mahogany) among the forest crops.

Table 3. Cropping patterns of farms located around each of the protected areas included in the study (see Table 1 for the elaboration of protected areas), and ANOVA-tests of differences between the four areas

\begin{tabular}{|c|c|c|c|c|c|c|c|c|}
\hline Crops/trees & CWS & TGR & RF 2 & RF 1 & Total & $\mathrm{F}$ & $\mathrm{df}$ & $\mathrm{p}$ \\
\hline \multicolumn{9}{|l|}{ Agricultural Crops } \\
\hline Rice $\left(\mathrm{m}^{2}\right)(\mathrm{N}=46)$ & $\begin{array}{c}6832.7 \pm \\
1706.4(\mathrm{~N}=13)\end{array}$ & $\begin{array}{c}5636.6 \pm \\
2240.3(\mathrm{~N}=15)\end{array}$ & $\begin{array}{c}6384.1 \pm \\
2469.9(\mathrm{~N}=11)\end{array}$ & $\begin{array}{c}2608.0 \pm \\
439.3(\mathrm{~N}=7)\end{array}$ & $\begin{array}{c}5692.51 \pm \\
2385.96(\mathrm{~N}=46)\end{array}$ & 7.4 & 3 & 0.0001 \\
\hline $\begin{array}{l}\text { Vegetable }\left(\mathrm{m}^{2}\right) \\
\qquad(\mathrm{N}=46)\end{array}$ & $\begin{array}{c}3529.6 \pm \\
1061.9(\mathrm{~N}=13)\end{array}$ & $\begin{array}{c}3345.3 \pm \\
1561.4(\mathrm{~N}=15)\end{array}$ & $\begin{array}{c}3435.0 \pm \\
1385.8(\mathrm{~N}=11)\end{array}$ & $\begin{array}{c}1178.9 \pm \\
136.4 \mathrm{~N}=7)\end{array}$ & $\begin{array}{c}3089.14 \pm \\
1470.77(\mathrm{~N}=46)\end{array}$ & 6.4 & 3 & 0.001 \\
\hline $\begin{array}{l}\text { Betel leaf }\left(\mathrm{m}^{2}\right) \\
\qquad(\mathrm{N}=12)\end{array}$ & $\begin{array}{c}363.3 \pm 77.7 \\
\quad(\mathrm{~N}=3)\end{array}$ & $\begin{array}{l}226.7 \pm 25.2 \\
\quad(\mathrm{~N}=3)\end{array}$ & $\begin{array}{c}276.7 \pm 92.9 \\
(\mathrm{~N}=3)\end{array}$ & $\begin{array}{c}600.0 \pm \\
100.0(\mathrm{~N}=3)\end{array}$ & $\begin{array}{c}366.67 \pm \\
164.335(\mathrm{~N}=12)\end{array}$ & 12.9 & 3 & 0.002 \\
\hline \multicolumn{9}{|l|}{ Horticultural Crops } \\
\hline $\begin{array}{c}\text { Jackfruit trees } \\
(\text { nos) }(\mathrm{N}=29)\end{array}$ & $\begin{array}{c}3.7 \pm 1.1 \\
(\mathrm{~N}=7)\end{array}$ & $\begin{array}{c}2.5 \pm 1.3 \\
(\mathrm{~N}=10)\end{array}$ & $\begin{array}{c}2.6 \pm 1.0 \\
(\mathrm{~N}=9)\end{array}$ & $\begin{array}{c}1.3 \pm 0.6 \\
(\mathrm{~N}=3)\end{array}$ & $\begin{array}{c}2.69 \pm 1.28 \\
(\mathrm{~N}=29)\end{array}$ & 3.4 & 3 & 0.033 \\
\hline $\begin{array}{l}\text { Banana trees } \\
(\text { nos })(\mathrm{N}=28)\end{array}$ & $\begin{array}{c}29.2 \pm 9.4 \\
(\mathrm{~N}=9)\end{array}$ & $\begin{array}{c}33.9 \pm 13.9 \\
(\mathrm{~N}=7)\end{array}$ & $\begin{array}{c}22.6 \pm 7.8 \\
(\mathrm{~N}=9)\end{array}$ & $\begin{array}{c}15.7 \pm 6.0 \\
(\mathrm{~N}=3)\end{array}$ & $\begin{array}{c}26.79 \pm 11.15 \\
(\mathrm{~N}=28)\end{array}$ & 3.1 & 3 & 0.046 \\
\hline $\begin{array}{l}\text { Coconut trees } \\
(\text { nos })(\mathrm{N}=25)\end{array}$ & $\begin{array}{c}2.4 \pm 1.3 \\
(\mathrm{~N}=9)\end{array}$ & $\begin{array}{c}4.6 \pm 1.3 \\
(\mathrm{~N}=5)\end{array}$ & $\begin{array}{c}2.9 \pm 0.9 \\
(\mathrm{~N}=7)\end{array}$ & $\begin{array}{c}1.7 \pm 0.5 \\
(\mathrm{~N}=4)\end{array}$ & $\begin{array}{c}2.88 \pm 1.424 \\
(\mathrm{~N}=25)\end{array}$ & 5.6 & 3 & 0.006 \\
\hline $\begin{array}{l}\text { Papaya trees (nos) } \\
\qquad(\mathrm{N}=18)\end{array}$ & $\begin{array}{c}5.0 \pm 3.6 \\
(\mathrm{~N}=4)\end{array}$ & $\begin{array}{c}12.2 \pm 5.3 \\
(\mathrm{~N}=4)\end{array}$ & $\begin{array}{c}3.8 \pm 1.3 \\
(\mathrm{~N}=5)\end{array}$ & $\begin{array}{c}5.6 \pm 2.9 \\
(\mathrm{~N}=5)\end{array}$ & $\begin{array}{c}6.44 \pm 4.514 \\
(\mathrm{~N}=18)\end{array}$ & 5.2 & 3 & 0.013 \\
\hline $\begin{array}{l}\text { Mango trees (nos) } \\
\qquad(\mathrm{N}=16)\end{array}$ & $\begin{array}{c}1.0 \pm 0.0 \\
(\mathrm{~N}=4)\end{array}$ & $\begin{array}{c}2.3 \pm 0.6 \\
(\mathrm{~N}=3)\end{array}$ & $\begin{array}{c}1.4 \pm 0.6 \\
(\mathrm{~N}=5)\end{array}$ & $\begin{array}{c}1.2 \pm 0.5 \\
(\mathrm{~N}=4)\end{array}$ & $\begin{array}{c}1.44 \pm 0.63 \\
(\mathrm{~N}=16)\end{array}$ & 5.1 & 3 & 0.017 \\
\hline $\begin{array}{l}\text { Black berry trees } \\
\quad(\text { nos })(\mathrm{N}=11)\end{array}$ & $\begin{array}{c}3.0 \pm 1.0 \\
(\mathrm{~N}=3)\end{array}$ & $\begin{array}{c}1.5 \pm 0.7 \\
(\mathrm{~N}=2)\end{array}$ & $\begin{array}{c}2.0 \pm 0.0 \\
(\mathrm{~N}=4)\end{array}$ & $\begin{array}{c}1.0 \pm 0.0 \\
(\mathrm{~N}=2)\end{array}$ & $\begin{array}{c}2.0 \pm 0.89 \\
(\mathrm{~N}=11)\end{array}$ & 5.1 & 3 & 0.035 \\
\hline \multicolumn{9}{|l|}{ Forest Crops } \\
\hline $\begin{array}{l}\text { Bamboo grooves } \\
(\text { nos) }(\mathrm{N}=30)\end{array}$ & $\begin{array}{c}1.8 \pm 0.8 \\
(\mathrm{~N}=9)\end{array}$ & $\begin{array}{c}3.0 \pm 1.5 \\
(\mathrm{~N}=7)\end{array}$ & $\begin{array}{c}3.0 \pm 1.7 \\
(\mathrm{~N}=9)\end{array}$ & $\begin{array}{c}7.0 \pm 5.7 \\
(\mathrm{~N}=5)\end{array}$ & $3.3 \pm 3.0(\mathrm{~N}=30)$ & 4.6 & 3 & 0.010 \\
\hline $\begin{array}{l}\text { Teak trees (nos) } \\
\qquad(\mathrm{N}=16)\end{array}$ & $\begin{array}{c}4.0 \pm 1.7 \\
(\mathrm{~N}=3)\end{array}$ & $\begin{array}{c}2.3 \pm 0.6 \\
(\mathrm{~N}=3)\end{array}$ & $\begin{array}{c}2.5 \pm 1.2 \\
(\mathrm{~N}=6)\end{array}$ & $\begin{array}{c}5.0 \pm 0.8 \\
(\mathrm{~N}=4)\end{array}$ & $\begin{array}{c}3.37 \pm 1.5 \\
(\mathrm{~N}=16)\end{array}$ & 4.8 & 3 & 0.020 \\
\hline $\begin{array}{c}\text { Mahogany trees } \\
(\text { nos) }(\mathrm{N}=21)\end{array}$ & $\begin{array}{c}1.7 \pm 0.5 \\
(\mathrm{~N}=8)\end{array}$ & $\begin{array}{c}1.6 \pm 0.9 \\
(\mathrm{~N}=5)\end{array}$ & $\begin{array}{c}1.8 \pm 1.1 \\
(\mathrm{~N}=5)\end{array}$ & $\begin{array}{c}1.3 \pm 0.6 \\
(\mathrm{~N}=3)\end{array}$ & $\begin{array}{c}1.6 \pm 0.78 \\
(\mathrm{~N}=21)\end{array}$ & 0.3 & 3 & 0.840 \\
\hline
\end{tabular}

Note: All values are mean \pm SD.

\subsection{Crop Loss From Crop Raiding Caused by Wild Elephants}

Crop loss due to crop raiding by wild elephants associated with agricultural crops, horticultural crops, and forest crops varied across the study areas (Table 4). Among the agricultural crops, on average, the greatest amount of crop loss, and the highest cost was associated with rice across all study areas. Among the horticultural crops, the greatest cost due to crop loss was incurred when elephants raided banana crops. The amount of the crop lost and 
the cost for the other fruit species was negligible, and no recorded losses occurred to the blackberry crops. Among the forest crops, the degree of the loss and the cost of elephant crop raiding associated with bamboo and teak crops significantly varied between the studies sites, but mahogany showed no such relationship. The average crop loss for most crops was higher in South-East Bangladesh than in the northern part of the country. The proportion of crop raiding incidents was higher in south-east Bangladesh (84.8\%) than in the northern part $(15.2 \%)$ of the country, and these figures significantly varied between these two regions $\left(\mathrm{N}=46, \chi^{2}=7.82, \mathrm{df}=\right.$ $1, \mathrm{P}=0.004)$.

Table 4. Crop loss and associated costs of crop raiding by elephants in each of the protected areas included in the study (see Table 1 for the elaboration of protected areas), and ANOVA-tests of differences between the four areas

\begin{tabular}{|c|c|c|c|c|c|c|c|c|}
\hline Crop loss and costs & CWS & TGR & RF 2 & RF 1 & Total & $\mathrm{F}$ & $\mathrm{df}$ & $\mathrm{p}$ \\
\hline \multicolumn{9}{|l|}{ Agricultural Crops } \\
\hline Rice $\left(\mathrm{m}^{2}\right)(\mathrm{N}=46)$ & $\begin{array}{c}399.1 \pm 103.9 \\
(\mathrm{~N}=13)\end{array}$ & $\begin{array}{c}422.7 \pm 117.2 \\
(\mathrm{~N}=15)\end{array}$ & $\begin{array}{c}385.2 \pm 126.9 \\
(\mathrm{~N}=11)\end{array}$ & $\begin{array}{c}238.0 \pm 28.9 \\
(\mathrm{~N}=7)\end{array}$ & $\begin{array}{c}378.96 \pm 121.26 \\
(\mathrm{~N}=46)\end{array}$ & 4.9 & 3 & 0.005 \\
\hline Rice $(\mathrm{Tk})(\mathrm{N}=46)$ & $\begin{array}{c}2738.3 \pm 767.4 \\
(\mathrm{~N}=13)\end{array}$ & $\begin{array}{c}2884.6 \pm \\
909.4(\mathrm{~N}=15)\end{array}$ & $\begin{array}{c}2729.1 \pm 841.1 \\
(\mathrm{~N}=11)\end{array}$ & $\begin{array}{c}1630.0 \pm \\
381.4(\mathrm{~N}=7)\end{array}$ & $\begin{array}{c}2615.15 \pm \\
879.58(\mathrm{~N}=46)\end{array}$ & 4.3 & 3 & 0.010 \\
\hline $\begin{array}{l}\text { Vegetable }\left(\mathrm{m}^{2}\right) \\
\qquad(\mathrm{N}=46)\end{array}$ & $\begin{array}{c}161.2 \pm 65.8 \\
(\mathrm{~N}=13)\end{array}$ & $\begin{array}{c}132.9 \pm 64.6 \\
(\mathrm{~N}=15)\end{array}$ & $\begin{array}{c}141.9 \pm 58.4 \\
(\mathrm{~N}=11)\end{array}$ & $\begin{array}{c}52.2 \pm 24.9 \\
(\mathrm{~N}=7)\end{array}$ & $\begin{array}{c}130.79 \pm 67.48 \\
(\mathrm{~N}=46)\end{array}$ & 5.4 & 3 & 0.003 \\
\hline $\begin{array}{c}\text { Vegetable (Tk) } \\
\quad(\mathrm{N}=46)\end{array}$ & $\begin{array}{c}2418.5 \pm 987.9 \\
(\mathrm{~N}=13)\end{array}$ & $\begin{array}{c}2090.9 \pm \\
1009.4(\mathrm{~N}=15)\end{array}$ & $\begin{array}{c}2145.4 \pm 912.9 \\
(\mathrm{~N}=11)\end{array}$ & $\begin{array}{c}784.4 \pm 376.8 \\
(\mathrm{~N}=7)\end{array}$ & $\begin{array}{c}1997.72 \pm \\
1034.34(\mathrm{~N}=46)\end{array}$ & 5.2 & 3 & 0.004 \\
\hline $\begin{array}{l}\text { Betel leaf }\left(\mathrm{m}^{2}\right) \\
\qquad(\mathrm{N}=12)\end{array}$ & $\begin{array}{c}146.7 \pm 30.6 \\
(\mathrm{~N}=3)\end{array}$ & $\begin{array}{c}91.7 \pm 10.4 \\
\quad(\mathrm{~N}=3)\end{array}$ & $\begin{array}{c}96.7 \pm 50.3 \\
\quad(\mathrm{~N}=3)\end{array}$ & $\begin{array}{c}240.0 \pm 40.0 \\
(\mathrm{~N}=3)\end{array}$ & $\begin{array}{c}143.75 \pm 69.38 \\
(\mathrm{~N}=12)\end{array}$ & 10.9 & 3 & 0.003 \\
\hline $\begin{array}{l}\text { Betel leaf }(\mathrm{Tk}) \\
\quad(\mathrm{N}=12)\end{array}$ & $\begin{array}{c}686.2 \pm 239.4 \\
(\mathrm{~N}=3)\end{array}$ & $\begin{array}{c}218.3 \pm 72.9 \\
(\mathrm{~N}=3)\end{array}$ & $\begin{array}{c}303.7 \pm 121.7 \\
(\mathrm{~N}=3)\end{array}$ & $\begin{array}{c}360.0 \pm 140.5 \\
(\mathrm{~N}=3)\end{array}$ & $\begin{array}{c}392.08 \pm 227.85 \\
(\mathrm{~N}=12)\end{array}$ & 5.2 & 3 & 0.028 \\
\hline \multicolumn{9}{|l|}{ Horticultural Crops } \\
\hline $\begin{array}{c}\text { Jackfruit (nos) } \\
\qquad(\mathrm{N}=29)\end{array}$ & $\begin{array}{c}4.5 \pm 1.4 \\
(\mathrm{~N}=7)\end{array}$ & $\begin{array}{c}5.7 \pm 1.9 \\
(\mathrm{~N}=10)\end{array}$ & $3.9 \pm 1.7(\mathrm{~N}=9)$ & $\begin{array}{c}2.8 \pm 0.3 \\
(\mathrm{~N}=3)\end{array}$ & $\begin{array}{c}4.58 \pm 1.81 \\
(\mathrm{~N}=29)\end{array}$ & 2.9 & 3 & 0.050 \\
\hline $\begin{array}{l}\text { Jackfruit (Tk) } \\
\qquad(\mathrm{N}=29)\end{array}$ & $\begin{array}{c}188.7 \pm 63.2 \\
\quad(\mathrm{~N}=7)\end{array}$ & $\begin{array}{c}221.9 \pm 67.4 \\
(\mathrm{~N}=10)\end{array}$ & $\begin{array}{c}157.0 \pm 59.8 \\
(\mathrm{~N}=9)\end{array}$ & $\begin{array}{c}112.7 \pm 12.7 \\
(\mathrm{~N}=3)\end{array}$ & $\begin{array}{c}182.46 \pm 68.16 \\
(\mathrm{~N}=29)\end{array}$ & 3.2 & 3 & 0.040 \\
\hline $\begin{array}{l}\text { Banana stalk (nos) } \\
\qquad(\mathrm{N}=28)\end{array}$ & $\begin{array}{c}26.3 \pm 8.5 \\
(\mathrm{~N}=9)\end{array}$ & $\begin{array}{c}30.5 \pm 12.5 \\
\quad(\mathrm{~N}=7)\end{array}$ & $\begin{array}{c}20.3 \pm 7.0 \\
(\mathrm{~N}=9)\end{array}$ & $\begin{array}{c}14.1 \pm 5.4 \\
(\mathrm{~N}=3)\end{array}$ & $\begin{array}{c}24.11 \pm 10.3 \\
(\mathrm{~N}=28)\end{array}$ & 3.1 & 3 & 0.046 \\
\hline $\begin{array}{c}\text { Banana stalk (Tk) } \\
\qquad(\mathrm{N}=28)\end{array}$ & $\begin{array}{c}8135.6 \pm \\
2565.7(\mathrm{~N}=9)\end{array}$ & $\begin{array}{c}8964.3 \pm \\
3937.8(\mathrm{~N}=7)\end{array}$ & $\begin{array}{c}6160.0 \pm 2173.6 \\
(\mathrm{~N}=9)\end{array}$ & $\begin{array}{c}3896.7 \pm \\
1436.7(\mathrm{~N}=3)\end{array}$ & $\begin{array}{c}7253.57 \pm \\
3101.3(\mathrm{~N}=28)\end{array}$ & 3.1 & 3 & 0.047 \\
\hline $\begin{array}{c}\text { Coconut (nos) } \\
(\mathrm{N}=25)\end{array}$ & $\begin{array}{c}10.2 \pm 6.2 \\
(\mathrm{~N}=9)\end{array}$ & $\begin{array}{c}19.4 \pm 6.1 \\
(\mathrm{~N}=5)\end{array}$ & $\begin{array}{c}13.4 \pm 4.8 \\
(\mathrm{~N}=7)\end{array}$ & $\begin{array}{c}6.8 \pm 2.1 \\
(\mathrm{~N}=4)\end{array}$ & $\begin{array}{c}12.4 \pm 6.56 \\
(\mathrm{~N}=25)\end{array}$ & 4.8 & 3 & 0.010 \\
\hline $\begin{array}{l}\text { Coconut (Tk) } \\
\qquad(\mathrm{N}=25)\end{array}$ & $\begin{array}{c}230.0 \pm 140.4 \\
(\mathrm{~N}=9)\end{array}$ & $\begin{array}{c}430.8 \pm 140.5 \\
(\mathrm{~N}=5)\end{array}$ & $\begin{array}{c}302.1 \pm 107.8 \\
(\mathrm{~N}=7)\end{array}$ & $\begin{array}{c}151.9 \pm 46.4 \\
(\mathrm{~N}=4)\end{array}$ & $\begin{array}{c}277.86 \pm 146.92 \\
(\mathrm{~N}=25)\end{array}$ & 4.6 & 3 & 0.013 \\
\hline $\begin{array}{l}\text { Papaya (nos) } \\
\quad(\mathrm{N}=17)\end{array}$ & $\begin{array}{c}20.7 \pm 12.8 \\
\quad(\mathrm{~N}=4)\end{array}$ & $\begin{array}{c}32.3 \pm 8.6 \\
(\mathrm{~N}=3)\end{array}$ & $8.8 \pm 2.4(\mathrm{~N}=5)$ & $\begin{array}{c}18.0 \pm 8.9 \\
(\mathrm{~N}=5)\end{array}$ & $\begin{array}{c}18.47 \pm 11.33 \\
(\mathrm{~N}=17)\end{array}$ & 4.8 & 3 & 0.020 \\
\hline $\begin{array}{l}\text { Papaya (Tk) } \\
\quad(\mathrm{N}=17)\end{array}$ & $\begin{array}{c}167.7 \pm 100.3 \\
(\mathrm{~N}=4)\end{array}$ & $\begin{array}{c}258.7 \pm 68.9 \\
(\mathrm{~N}=3)\end{array}$ & $\begin{array}{c}91.4 \pm 30.1 \\
(\mathrm{~N}=5)\end{array}$ & $\begin{array}{c}135.4 \pm 62.7 \\
(\mathrm{~N}=5)\end{array}$ & $\begin{array}{c}151.82 \pm 84.37 \\
(\mathrm{~N}=17)\end{array}$ & 4.0 & 3 & 0.031 \\
\hline $\begin{array}{l}\text { Mango (nos) } \\
\qquad(\mathrm{N}=16)\end{array}$ & $\begin{array}{c}1.2 \pm 0.9 \\
(\mathrm{~N}=4)\end{array}$ & $\begin{array}{c}6.3 \pm 2.1 \\
(\mathrm{~N}=3)\end{array}$ & $4.0 \pm 1.9(\mathrm{~N}=5)$ & $\begin{array}{c}3.7 \pm 1.5 \\
(\mathrm{~N}=4)\end{array}$ & $\begin{array}{c}3.69 \pm 2.27 \\
(\mathrm{~N}=16)\end{array}$ & 5.6 & 3 & 0.012 \\
\hline $\begin{array}{l}\text { Mango (Tk) } \\
\quad(\mathrm{N}=16)\end{array}$ & $\begin{array}{c}17.1 .0 \pm 13.3 \\
(\mathrm{~N}=4)\end{array}$ & $\begin{array}{c}61.2 \pm 30.1 \\
\quad(\mathrm{~N}=3)\end{array}$ & $\begin{array}{c}45.9 \pm 23.8 \\
\quad(\mathrm{~N}=5)\end{array}$ & $\begin{array}{c}19.3 \pm 9.9 \\
(\mathrm{~N}=4)\end{array}$ & $\begin{array}{c}34.9 \pm 25.58 \\
(\mathrm{~N}=16)\end{array}$ & 4.0 & 3 & 0.034 \\
\hline \multicolumn{9}{|l|}{ Forest Crops } \\
\hline $\begin{array}{c}\text { Bamboo (nos) } \\
(\mathrm{N}=30)\end{array}$ & $\begin{array}{c}13.8 \pm 7.9 \\
(\mathrm{~N}=9)\end{array}$ & $\begin{array}{c}22.1 \pm 12.1 \\
(\mathrm{~N}=7)\end{array}$ & $\begin{array}{c}24.8 \pm 14.9 \\
(\mathrm{~N}=9)\end{array}$ & $\begin{array}{c}56.4 \pm 46.6 \\
(\mathrm{~N}=5)\end{array}$ & $\begin{array}{c}26.13 \pm 24.87 \\
(\mathrm{~N}=30)\end{array}$ & 4.4 & 3 & 0.012 \\
\hline
\end{tabular}




\begin{tabular}{|c|c|c|c|c|c|c|c|c|}
\hline $\begin{array}{l}\text { Bamboo (Tk) } \\
(\mathrm{N}=30)\end{array}$ & $\begin{array}{c}205.9 \pm 117.5 \\
(\mathrm{~N}=9)\end{array}$ & $\begin{array}{c}311.9 \pm 184.4 \\
(\mathrm{~N}=7)\end{array}$ & $\begin{array}{c}346.9 \pm 209.0 \\
(\mathrm{~N}=9)\end{array}$ & $\begin{array}{c}789.6 \pm 652.9 \\
(\mathrm{~N}=5)\end{array}$ & $\begin{array}{c}370.2 \pm 348.4 \\
(\mathrm{~N}=30)\end{array}$ & 4.2 & 3 & 0.015 \\
\hline Teak (nos) $(\mathrm{N}=16)$ & $\begin{array}{c}1.7 \pm 0.6 \\
(\mathrm{~N}=3)\end{array}$ & $\begin{array}{c}1.3 \pm 0.5 \\
(\mathrm{~N}=3)\end{array}$ & $0.7 \pm 0.5(\mathrm{~N}=6)$ & $\begin{array}{c}2.0 \pm 0.8 \\
(\mathrm{~N}=4)\end{array}$ & $\begin{array}{c}1.31 \pm 0.79 \\
(\mathrm{~N}=16)\end{array}$ & 4.1 & 3 & 0.032 \\
\hline Teak $(\mathrm{Tk})(\mathrm{N}=16)$ & $\begin{array}{c}11500.0 \pm \\
3774.9(\mathrm{~N}=3)\end{array}$ & $\begin{array}{c}8166.7 \pm \\
1755.9(\mathrm{~N}=3)\end{array}$ & $\begin{array}{c}5333.3 \pm 4131.2 \\
(\mathrm{~N}=6)\end{array}$ & $\begin{array}{c}13500.0 \pm \\
5196.1(\mathrm{~N}=4)\end{array}$ & $\begin{array}{c}9062.5 \pm \\
5055.98(\mathrm{~N}=16)\end{array}$ & 3.6 & 3 & 0.045 \\
\hline $\begin{array}{l}\text { Mahogany (nos) } \\
\quad(\mathrm{N}=21)\end{array}$ & $\begin{array}{c}0.9 \pm 0.9 \\
(\mathrm{~N}=8)\end{array}$ & $\begin{array}{c}0.8 \pm 1.8 \\
(\mathrm{~N}=5)\end{array}$ & $0.4 \pm 0.5(\mathrm{~N}=5)$ & $\begin{array}{c}0.0 \pm 0.0 \\
(\mathrm{~N}=3)\end{array}$ & $\begin{array}{c}0.62 \pm 1.07 \\
(\mathrm{~N}=21)\end{array}$ & 0.6 & 3 & 0.646 \\
\hline $\begin{array}{l}\text { Mahogany (Tk) } \\
\quad(\mathrm{N}=21)\end{array}$ & $\begin{array}{c}4312.0 \pm \\
4978.1(\mathrm{~N}=8)\end{array}$ & $\begin{array}{c}4000.0 \pm \\
8944.3(\mathrm{~N}=5)\end{array}$ & $\begin{array}{c}1500.0 \pm 2061.6 \\
(\mathrm{~N}=5)\end{array}$ & $\begin{array}{c}0.0 \pm 0.0 \\
(\mathrm{~N}=3)\end{array}$ & $\begin{array}{c}2952.38 \pm \\
5326.59(\mathrm{~N}=21)\end{array}$ & 0.6 & 3 & 0.604 \\
\hline
\end{tabular}

Note: All values are mean \pm SD.

The cost due to crop loss caused by the elephants varied significantly with the distance of the farm from the park boundary, the timing and season of the crop raiding incident, and the herd size of the crop-raiding elephants (Table 5). An increasing degree of crop loss due to raiding by wild elephants occurred between $200 \mathrm{~m}$ and $300 \mathrm{~m}$ from the park boundary. After $300 \mathrm{~m}$, however, the degree of high crop loss decreased significantly. The highest proportion of small losses was recorded during the early evening $(19.00$ to $21.00 \mathrm{~h})$, while the greatest proportion of high losses occurred during the late evening $(21.00$ to $24.00 \mathrm{~h})$. The linear regression showed that the total cost derived from crop-raiding was significantly related to the duration of the crop-raiding incident $\left(\mathrm{r}^{2}=\right.$ $0.424, \beta=128.9, \mathrm{t}=5.7, \mathrm{df}=1, \mathrm{P}<0.001)$. Costs due to crop damage increased with increasing crop-raiding time. Wild elephants raided crops throughout most of the year, but the greatest proportion of high crop losses were recorded during the monsoon season (i.e., June to September), while the highest proportion of small losses occurred during the post-monsoon season (i.e., October to December). More than two-thirds of the high losses due to crop raids were inflicted by herds of four elephants.

Table 5. Percentage of crops lost in relation to distance from protected areas; crop raiding time, month, and herd size of wild elephants. $\chi^{2}$ tests of independence between small and high crop loss

\begin{tabular}{|c|c|c|c|c|c|c|}
\hline & \multicolumn{3}{|c|}{ Cost of crop loss } & \multicolumn{3}{|c|}{ Statistics } \\
\hline & $\begin{array}{c}\text { Small loss }(<\mathrm{Tk} 14206) \\
\qquad(\mathrm{N}=25)\end{array}$ & $\begin{array}{c}\text { High loss }(>\mathrm{Tk} 14206) \\
(\mathrm{N}=21)\end{array}$ & $\begin{array}{c}\text { Total } \\
(\mathrm{N}=46)\end{array}$ & $\chi^{2}$ & $\mathrm{df}$ & $\mathrm{p}$ \\
\hline \multicolumn{7}{|l|}{ Distances of Farm From Park } \\
\hline$<100 \mathrm{~m}$ & 28.0 & 9.5 & 19.6 & & & \\
\hline 101 to $200 \mathrm{~m}$ & 44.0 & 9.5 & 28.3 & & & \\
\hline 201 to $300 \mathrm{~m}$ & 28.0 & 52.4 & 39.1 & & & \\
\hline$>300 \mathrm{~m}$ & 0.0 & 28.6 & 13.0 & 15.7 & 3 & 0.001 \\
\hline \multicolumn{7}{|l|}{ Timing of Crop Raiding } \\
\hline Early evening (19-21 h/7-9 pm) & 64.0 & 14.3 & 41.3 & & & \\
\hline Late evening (21-24 h/9-12 pm) & 20.0 & 71.4 & 43.5 & & & \\
\hline Night (0-6 h/1-6 am) & 16.0 & 14.3 & 15.2 & 13.8 & 2 & 0.001 \\
\hline \multicolumn{7}{|l|}{ Crop Raiding Months } \\
\hline Pre-monsoon (January to May) & 24.0 & 0.0 & 13.0 & & & \\
\hline Monsoon (June to September) & 20.0 & 71.4 & 43.5 & & & \\
\hline Post-monsoon (October to December) & 56.0 & 28.6 & 43.5 & 13.9 & 2 & 0.001 \\
\hline \multicolumn{7}{|l|}{ Herd Size During Crop Raid } \\
\hline 2 elephants & 60.0 & 23.8 & 43.5 & & & \\
\hline 3 elephants & 32.0 & 4.8 & 19.5 & & & \\
\hline 4 elephants & 8.0 & 66.6 & 34.8 & & & \\
\hline 5 elephants & 0.0 & 4.8 & 2.2 & 20.2 & 3 & 0.0001 \\
\hline
\end{tabular}




\subsection{People's Perceptions Towards Wild Elephants as A Pest}

More than half of the farmers (58.7\%) considered the elephant an agricultural pest. There was no significant difference in these perceptions among the study areas $\left(\chi^{2}=4.4, \mathrm{df}=3, \mathrm{P}=0.219\right)$. The farmers' views on elephants as an agricultural pest did vary significantly with the distance of the farm from the park boundary, monthly income, education, occupation, crop loss, and farm size, but there was no significant correlation with the settlement status of the farmer (Table 6). More than $95 \%$ of the farmers within $200 \mathrm{~m}$ of the park boundary considered elephants a pest, whereas approximately $25 \%$ of those who lived further held this belief. Similarly, the majority of the farmers who considered elephants a pest species were poor, illiterate small-scale farmers. The farmers who experienced < Tk 14206 in crop loss were more likely to consider the elephant a pest, while those with high losses were less likely to hold this view. Similarly, small-scale farmers were more likely than large-scale farmers to regard elephants as a pest. The results of the study indicated that the percentage of the loss of farmers' annual income significantly varied between farm size $\left(\chi^{2}=9.2, \mathrm{df}=3, \mathrm{P}=0.027\right)$. The majority of the farmers (71.7\%) reported that wild elephants caused crop damage that cost them $25 \%$ of their annual income. Among them, $76.2 \%$ had a small farm, while $68 \%$ had large farms. One fifth of the farmers $(19.6 \%)$ reported that wild elephants caused a $25-50 \%$ loss of their annual income, of which $4.8 \%$ owned small farms and $32 \%$ owned large farms. Very few farmers (4.3\%) reported that they lost more than $50 \%$ of their annual income due to crop loss from crop raiding by elephants.

Table 6. Percentage of farmers with perceptions of elephants as pests in relation to socio-economic and demographic factors, and $\chi^{2}$ tests of independence between the responses of farmers.

\begin{tabular}{|c|c|c|c|c|c|c|}
\hline \multirow{2}{*}{\multicolumn{2}{|c|}{ Factors influencing the perceptions }} & \multicolumn{2}{|c|}{ Are elephants a pest? } & \multicolumn{3}{|c|}{ Statistics } \\
\hline & & \multirow{2}{*}{$\begin{array}{l}\text { No }(\mathrm{N}=19) \\
4.5\end{array}$} & \multirow{2}{*}{$\begin{array}{l}\text { Yes }(\mathrm{N}=27) \\
95.5\end{array}$} & \multirow[t]{2}{*}{$\chi^{2}$} & \multirow[t]{2}{*}{$\mathrm{df}$} & \multirow[t]{2}{*}{$\mathrm{p}$} \\
\hline Dintono of fom from nol & $<200 \mathrm{~m}$ & & & & & \\
\hline Distance of farm from park & $>200 \mathrm{~m}$ & 75.0 & 25.0 & 23.5 & 1 & 0.0001 \\
\hline \multirow{2}{*}{ Monthly income } & Poor & 9.1 & 90.9 & & & \\
\hline & Rich & 70.8 & 29.2 & 18.0 & 1 & 0.0001 \\
\hline \multirow{2}{*}{ Education of respondent } & Illiterate & 8.3 & 91.7 & & & \\
\hline & Literate & 77.3 & 22.7 & 22.5 & 1 & 0.0001 \\
\hline \multirow{2}{*}{ Occupation of respondent } & Small farmers & 4.8 & 95.2 & & & \\
\hline & Large farmers & 72.0 & 28.0 & 21.3 & 1 & 0.0001 \\
\hline \multirow{2}{*}{ Crop loss } & Small loss $(<\mathrm{Tk} 14206)$ & 28.0 & 72.0 & & & \\
\hline & High loss (> Tk 14206) & 57.1 & 42.9 & 3.9 & 1 & 0.046 \\
\hline \multirow{2}{*}{ Farm size } & Small farm & 4.8 & 95.2 & & & \\
\hline & Large farm & 72.0 & 28.0 & 21.3 & 1 & 0.0001 \\
\hline \multirow{2}{*}{ Settlement status } & Residents & 52.0 & 48.0 & & & \\
\hline & Immigrant & 28.6 & 71.4 & 2.6 & 1 & 0.108 \\
\hline
\end{tabular}

A stepwise linear regression with responses to the question, "Have you considered the wild elephant as an agricultural pest on your farm?" as the dependent variable was used to test how much of the variation in perception was explained by the nine independent variables (Table 7). Only three of these variables were found to be significant contributors to the variation in the farmers' perceptions. The variable explaining the greatest amount of variation in perception was the education level of the farmers. Illiterate farmers were significantly more likely to consider elephants a pest than literate farmers. The distance of the farm from the protected areas was the second-most important predictor of farmers' attitudes; farmers who regarded the elephants as a pest generally had farms closer to the park boundary. Another significant factor was the amount of crop loss in terms of cost incurred from crop raiding. Respondents who experienced greater losses were more likely to consider elephants as agricultural pest. No other independent variable had a significant correlation with the farmers' perceptions of elephants as pests. Together, all independent variables explained $64.2 \%$ of the variation in farmers ' perceptions of wild elephants as agricultural pest. 
Table 7. Results of a stepwise linear regression analysis with farmers' perceptions of elephants as pests as a dependent variable in relation to various independent variables

\begin{tabular}{ccccc}
\hline Independent variables & $\mathrm{R}$ & $B$ & $t$ & $p$ \\
\hline Education & 1 & -0.599 & -2.545 & 0.015 \\
Distance of farm from the park & 2 & -0.271 & -2.453 & 0.019 \\
Crop loss and associated cost (Tk) & 3 & 0.262 & 2.055 & 0.047 \\
Settlement status & 4 & -0.238 & -1.809 & 0.079 \\
Investment (Tk) & 5 & 0.397 & 0.882 & 0.384 \\
Age & 6 & -0.005 & -0.737 & 0.466 \\
Household size & 7 & -0.015 & -0.642 & 0.525 \\
Occupation & 8 & -0.201 & -0.488 & 0.628 \\
Monthly income (Tk) & 9 & -0.098 & -0.344 & 0.733 \\
Constant & & 2.260 & 5.573 & 0.0001 \\
\hline
\end{tabular}

Note: $\mathrm{R}=$ rank; $\mathrm{t}=\mathrm{t}$ value; $\mathrm{R}^{2}=0.642 ; \mathrm{p}=0.0001$.

\section{Discussion}

This study revealed that the proportion of crop raiding by wild elephants is greater in the South-East region of Bangladesh (i.e., CWS, TGR, and RF 2) than in the Northern part (i.e., RF 1) of the country. South-Eastern Bangladesh has been considered as fundamental habitat for Asian elephants in this country. In the North, by contrast, crop raiding incidents are seasonal and occur during the post-monsoon season (Sarker \& Røskaft, 2010) . The area surrounding the Northern region is a flood-prone zone where most of the inhabitants are involved in non-farming activities during the monsoon season due to the flooding of their crop fields and their preferences for farming after the monsoon. During the peak agricultural crop season, however, elephants seek suitable fields for foraging and continue raiding until the farmers retaliate (Sukumar, 1989).

This study also revealed that rice and vegetables have the greatest economic losses due to crop raiding by elephants. Rice and various vegetables are cultivated in two distinct seasons [i.e., monsoon (June - September) and post-monsoon (October-December)] in Bangladesh. Elephants usually raid rice fields while the grain is maturing and continue their raids until the harvest is complete. The frequency of raiding peaks during the rice crop seasons, when a large area is cultivated. During this period, vegetables and betel leaves are also grown; elephants raid these crops, thereby inflicting the greatest losses. These crops are the most abundantly planted, so the raiding might be opportunistic, as opposed to the more commonly held view of these raids as being preferential. Elephants with a surplus of natural food resources still resorted to crop raiding. They were most likely attracted by the greater palatability and food value of the cultivated plants (Hart \& O'Connell, 2000). Moreover, crops are more easily digested than food items available in the wild (Rode, Chiyo, Chapman \& McDowell, 2006). This study reveals that in home gardens, bananas are attacked at all stages of development. Elephants also forage on the other fruit crops such as jackfruit, coconut, papaya, and mango as well as forest crops such as bamboo and teak, particularly when agricultural crops are not available on their usual raiding routes. Our study further revealed that the crop damage is greater in agricultural farms than in home gardens because agricultural farms are generally found in encroached forest patches adjoining human settlements in the protected areas. The farmers also explained that the crop damage was recorded as low in home gardens because home gardens are planted in the same locations as human settlements. Elephants are not inclined to risk this type of crop raiding as the farmers will retaliate. The farmers believe that elephants are intelligent animals that understand human movements and that elephants intentionally raid crops by avoiding the artificial barriers erected by farmers.

Elephant herds largely confine their forays to within $1 \mathrm{~km}$ of the forest boundary (Sukumar, 1989). Elephants are more likely to raid along boundaries rather than go deep into farming areas because the risk of detection is lowest in areas that serve as a buffer between protected areas and areas cleared for cultivation (Bandara \& Tisdell , 2002). We found that elephant crop-raiding incidents mostly occurred close to the park boundary (within 300 $\mathrm{m})$. We also found that farms were smaller closer to the park boundary and became larger farther from the protected areas. Therefore, crop loss increased with farm distance up to $300 \mathrm{~m}$ from the park boundary, but loss decreased at greater distances because there was a greater chance of farmer retaliation due to a higher human 
settlement density at distances beyond 300 meters in comparison to those closer to the park boundary.

Elephants enter crop fields only after dark, and during the crop season, elephants usually move close to the forest-village boundary in the early evening (Sukumar, 1989). Fields, however, are not generally guarded on a 24-hour basis and are tended only during the daylight hours. Most of the crop raiding, therefore, takes place at night when the fields are unattended. Farmers construct thatched houses (huts) during the harvest season (especially the rice harvest) to guard their fields at night. Such guarding activities are always carried out in groups (Sarker \& Røskaft, 2010). Therefore, in the early evening, large guard groups make it possible to guard against crop raiding and drive elephants from the field. However, farmers are unable to maintain large groups throughout the late evening due to a lack of sleep. Moreover, they are financially unable to hire night guards. Thus, the highest proportion of small losses occurred during the early evening due to the high guarding intensity, but the greatest proportion of large losses occurred in late evening because of the low guarding intensity. Another reason for the timing of crop-raiding is that the elephants are staying in the field more frequently during the late evening compared to the early evening. Naughton et al. (1999) noted that a fear of elephants also motivates people to stay away from their fields at night. The risks and benefits of crop raiding differ between the sexes of elephants (Sukumar, 2004). The bull elephants have a greater impact on crops, even though they commonly travel alone, inflicting far more damage than even a herd of several female elephants, and crop raiding is habitual for some adult bulls. We could not determine the sex of the elephants in the field at night.

Negative attitudes, unpleasant experiences, and economic damages resulting from crop raiding by elephants motivate farmers to treat crop-raiding elephants harshly (Bandara \& Tisdell, 2002). Most interviewed farmers considered elephants a pest. However, the farmers who held this attitude suffered less crop damage at the boundaries of nature reserves than those whose farms were farther from the park. It is probable that crop losses incurred from crop raiding have more severe impacts on the livelihood of farmers closer to the park boundary because they have small farms. Illiteracy may shape negative attitudes of farmers because they are less likely to receive information about the importance of conservation and the reality of the crop-raiding problem compared to literate farmers.

The farmers' complaints about wild elephants as agricultural pests were closely associated with at least three major issues: an increase in the intensity of the crop damage, the ineffectiveness of crop protection measures and poor compensation for crop damage, which lowered the farmers' tolerance for the presence of elephants in the fields. The lack of compensation, or insufficient compensation, furthermore causes farmers to exaggerate and distort the issue (Bauer, 2003; Madhusudan, 2003; Sekhar, 1998; Weladji \& Tchamba, 2003). Bangladesh needs new policies and programmes for elephant conservation and for the mitigation of farmer conflicts with park management. Such policies must adequately address compensation to farmers for the agricultural and property damage caused by raiding elephants. On the one hand, without such compensation, farmers will not tolerate elephants near or on their farms, and they will extract more natural resources from the park to make their living and recover economic losses from the crop damage caused by the elephants; on the other hand, compensation schemes are notoriously hard to manage and are prone to fraud and moral hazard. In Bangladesh, many farmers consider the elephant a dangerous pest, similar to any other pest that disturbs their crop production, farming practices and social well-being. Although elephants may cause considerable damage at the local level (Dudley, Mensah-Ntiamoah, \& Kpelle, 1992), their regional impact on agriculture is insignificant compared to other vertebrate and invertebrate pests (Naughton, Rose, \& Treves, 1999). Elephants depredate at a high intensity for only a few months of the year; the damage caused by wild boars and porcupines is reported to be lower, but it is continuous. However, compensation for human-wildlife conflicts can be tied to land rights. For example, in the Bhadra Tiger Reserve in India, claimants without evidence of land tenure were not compensated for livestock or crop losses (Madhusudan, 2003). A positive impact on community attitudes towards conservation has been reported in several studies where extraction rights have been granted, despite crop and livestock losses (Bajracharya, Furley, \& Newton, 2006; Studsrød \& Wegge, 1995). In addition to education, financial compensation for crop damage can be very effective in low-income areas if compensation is distributed fairly and if corruption does not interfere (Bulte \& Rondeau, 2007), but such schemes are difficult to conduct if government funds are lacking. Alternative methods of compensation could include free permits to collect forest resources, such as grass, an approach that has been successful in Nepal (Weladji \& Tchamba, 2003). In light of the above circumstances, to help ensure the long-term conservation of wild elephants and the mitigation of the elephant pest problem, Bangladesh needs integrated policies regarding land use, compensation schemes, and education involving both public and private stakeholders, including farmers. Moreover, changing in cropping pattern can be alternative options to reduce the conflict between farmers and wild elephants. Farmers could shift to non edible timber species instead of paddy and vegetable crops and government should provide 
incentives per annum basis until non-edible timber species enter to profits. In addition, government should taken an action to improve the core zones of protected areas along the range of elephants habitat in order to establish availability of natural sources for the avoidance of elephant herd entry into the crop fields located near the park boundary. Such actions are especially needed because the resources available to elephants in protected areas are insufficient to ensure the long-term survival of the Asian elephant in Bangladesh.

\section{Conclusion}

Most farmers considered elephants to be agricultural pests, revealing that elephants are a source of social conflict. Thus, any plan for conservation without adequate provision for human interests is bound to fail (Sarker \& Røskaft, 2011b). The conservation and appropriate management of the Asian elephant, however, requires that social conflicts be resolved, and therefore, policymakers seeking practical solutions to conservation issues must go well beyond the economic evaluation of such species. The long-term survival of wild elephants depends on the development of a scheme to compensate farmers adequately for the damages they suffer from elephant raids.

\section{References}

Allaway, J. D. (1979). Elephants and their interactions with people in the Tana River region of Kenya. Cornell University.

Aung, A. (1997). On the distribution, status and conservation of wild elephant in Myanmar. Gajah, 18, 21-27.

Bajracharya, S. B., Furley, P. A., \& Newton, A. C. (2006). Impacts of community-based conservation on local communities in the Annapurna Conservation area, Nepal. Biodiversity and Conservation, 15, 2765-2786. http:// dx.doi.org/10.1007/s10531-005-1343-x

Bandara, R., \& Tisdell, C. (2002). Asian elephants as agricultural pests: damages, economics of control and compensation in Sri Lanka. Natural Resources Journal, 42, 491-519.

Barnes, R. F. W. (1996). The conflict between humans and elephants in the central African forests. Mammal Review, 26(2-3), 67-80.

Bauer, H. (2003). Local perceptions of Waza National Park, northern Cameroon. Environmental Conservation, 30(2), 175-181. http://dx.doi.org/10.1017/S037689290300016X.

BBS. (2009). Statistical year book. Government of People's Republic of Bangladesh.

Bell, R. H. V. (1984). The man-animal interface: an assessment of crop damage and wildlife control. In R. H. V. Bell \& E. McShane-Caluzi (Eds.). Conservation and wildlife management in Africa (pp. 387-446). Malawi: U.S. Peace Corps Office of Training and Program Support.

Bulte, E., \& Rondeau, D. (2007). Compensation for wildlife damages: Habitat conversion, species preservation and local welfare. Journal of Environmental Economics and Management, 54(3), 311-322. http://dx.doi.org/10.1016/j.jeem.2007.02.003.

Daniel, J. C. (1996). Conservation of Asian elephant. Gajah, 19, 9-16.

de Boer, W. F., \& Baquete, D. S. (1998). Natural resource use, crop damage and attitudes of rural people in the vicinity of the Maputo Elephant Reserve, Mozambique. Environmental Conservation, 25(3), 208-218. http://dx.doi.org/10.1017/S0376892998000265

Dixon, J. A., \& Sherman, P. B. (1990). Economics of protected areas: A new look at benefits and costs. London, UK: Earthscan Publications.

Dublin, H. T., \& Hoare, R. E. (2004). Searching for solutions: the evolution of an integrated approach to understanding and mitigating human-elephant conflict in Africa. Human Dimensions of Wildlife, 9, 271-278. http://dx.doi.org/10.1080/10871200490505701

Dudley, J. P., Mensah-Ntiamoah, A. Y., \& Kpelle, D. G. (1992). Forest elephants in a rainforest fragment: preliminary findings from a wildlife conservation project in southern Ghana. African Journal of Ecology, 30, 116-126.

Gillingham, S. (1998). Giving wildlife a value: A case study of community wildife management around the Selous Game Reserve, Tanzania. PhD thesis, University of Cambridge.

Gillingham, S., \& Lee, P. C. (1999). The impact of wildlife-related benefits on the conservation attitudes of local people around the Selous Game Reserve, Tanzania. Environmental Conservation, 26(3), 218-228. http://dx.doi.org/10.1017/S0376892999000302

Gillingham, S., \& Lee, P. C. (2003). A preliminary assessment of perceived and actual patterns of wildlife crop 
damage in an area bordering the Selous Game Reserve, Tanzania. Oryx, 37, 316-325. http://dx.doi.org/10.1017/S0030605303000577

Hart, L. A., \& O'Connell, C. E. (1998). Human conflict with African and Asian Elephants and associated conservation dilemmas. Center for Animals in Society in the School of Veterinary Medicine and Ecology Graduate Group.

Hart, L. A., \& O'Connell, C. E. (2000). Human conflict with African and Asian elephants and associated conservation dilemmas. Center for Animals in Society in the School of Veterinary Medicine and Ecology, University of California.

Hill, C. M. (1997). Crop-raiding by wild vertebrates: the farmer's perspective in an agricultural community in Western Uganda. International Journal of Pest Management, 43(11), 77-84.

Hill, C. M. (1998). Conflicting attitudes towards elephants around the Budongo Forest Reserce, Uganda. Environmental Conservation, 26, 218-228. http://dx.doi.org/10.1017/S0376892998000307

Infield, M. (1988). Attitudes of a rural community towards conservation and a local conservation area in Natal, South Africa. Biological Conservation, 45, 21-46. http://dx.doi.org/10.1016/0006-3207(88)90050-X

IUCN. (1994). IUCN Red List Categories. IUCN Species Survival Commission.

Khan, M. H., Khan, S. M., \& Biswas, S. R. (2004). Human-elephant conflicts in Bangladesh and assessment of financial losses. Conservation of Asian elephants in Bangladesh. IUCN-The World Conservation Union, Bangladesh Country Office, Technical Report.

Kotagama, S. W. (1997). Interaction its nature and trends. Proceedings of the Seminar on Conservation Plan for Elephants of Sri Lanka, Department of Wildlife Conservation, Colombo, Sri Lanka, 1997. United State Agency for International Development.

Laudati, A. A. (2010). The encroaching forest: struggles over land and resources on the boundary of Bwindi Impenetrable National Park, Uganda. Society \& Natural Resources, 23, 776-789. http://dx.doi.org/10.1080/08941920903278111

Lee, P. C., \& Priston, N. E. C. (2005). Perceptions of pests: human attitudes to primates, conflict and consequences for conservation. In J. D. Paterson \& J. W. Wallis (Eds.). Commensalism and conflict: The human-primate interface (pp. 1-23). Norman: American Society of Primatology.

Mackenzie, C. A., \& Ahabyona, P. (2012). Elephants in the garden: Financial and social costs of crop raiding. Ecological Economics, 75, 72-82. http://dx.doi.org/10.1016/j.ecolecon.2011.12.018

Madhusudan, M. D. (2003). Living amidst large wildlife: Livestock and crop depredation by large mammals in the interior villages of Bhadra Tiger Reserve, south India. Environmental Management, 31(4), 466-475. http://dx.doi.org/10.1007/s00267-002-2790-8

Mwathe, K. M. (1992). A preliminary report on elephant crop damage in areas bordering Shimba Hills National Reserve. Kenya Wildlife Service Elephant Program.

Naughton-Treves, L. (1997). Farming the forest edge: Vulnerable places and people around Kibale National Park, Uganda. The Geographical Review, 87,27-46. http://dx.doi.org/10.2307/215656

Naughton-Treves, L. (1998). Predicting patterns of crop damage by wildlife around Kibale National Park, Uganda. Conservation Biology, 12(1), 156-168. http://dx.doi.org/10.1046/j.1523-1739.1998.96346.x

Naughton, L., Rose, R., \& Treves, A. (1999). The social dimensions of human-elephant conflict in Africa: A literature review and case studies from Uganda and Cameroon. University of Wisconsin, Geography, Z.

Newmark, W. D., Manyanza, D. N., Gamassa, D. G. M., \& Sariko, H. I. (1994). The conflict between wildlife and local people living adjacent to protected areas in Tanzania - Human density as a predicator. Conservation Biology, 8(1), 249-255. http://dx.doi.org/10.1046/j.1523-1739.1994.08010249.x

Nyhus, P. J., Tilson, R., \& Sumianto, P. (2000). Crop-raiding elephants and conservation implications at Way Kambas National Park, Sumatra, Indonesia. Oryx, 34(4), 262-274, http://dx.doi.org/10.1046/j.1365-3008.2000.00132.x

Oerke, E. C., Dehne, H. W., Schonbeck, F., \& Weber, A. D. (1994). Crop production and crop protection: Estimated losses in major food and cash crops. Amsterdam: Elsevier.

Osborn, F. V., \& Parker, G. E. (2003). Towards an integrated approach for reducing the conflict between elephants and people: a review of current research. Oryx, 37(1), 80-84. 
http://dx.doi.org/10.1017/S0030605303000152

Ramakrishnan, R., Sivaganesan, N., \& Srivatava, R. (1997). Human interference and its impact on elephant corridors in South India. Gajah, 18, 1-21.

Rode, K. D., Chiyo, P. I., Chapman, C. A., \& McDowell, L. R. (2006). Nutritional ecology of elephants in Kibale National Park, Uganda, and its relationship with crop-raiding behaviour. Journal of Tropical Ecology, 2, 441-449. http://dx.doi.org/10.1017/S0266467406003233

Roe, D., \& Elliott, J. (2006). Pro-poor conservation: The elusive win-win for conservation and povert reduction? Policy Matters (Vol. 2014, pp. 53-63).

Røskaft, E., Larsen, T., Mojaphoko, R., Sarker, A. H. M. R., \& Jackson, C. (2014). Human dimensions of elephant ecology. In J. Du Toit, C. Skarpe, \& S. Moe (Eds.). Elephants and Savanna Woodland Ecosystems: A study from Chobe National Park, Botswana (pp. 269-288). 12.05.2012 (draft edition). Oxford: John Wiley and Sons, Ltd.

Sarker, A. H. M. R. (2010). Human-wildlife conflict: A comparison between Asia and Africa with special reference to elephants. In E. Gereta \& E. Røskaft (Eds.). Conservation of natural resources; some African \& Asian examples (pp. 186-210). Trondheim: Tapir academic press.

Sarker, A. H. M. R., \& Røskaft, E. (2010). Human attitudes towards conservation of Asian elephants (Elephas maximus) in Bangladesh. International Journal of Biodiversity and Conservation, 2(10), 316-327.

Sarker, A. H. M. R., \& Røskaft, E. (2011a). Human-wildlife conflicts and management options in Bangladesh with speicial reference to Asian elephants (Elephas maximus). International Journal of Biodiversity Science, Ecosystem Services \& Management, 6(3), 164-175. http://dx.doi.org/10.1080/21513732.2011.554867

Sarker, A. H. M. R., \& Røskaft, E. (2011b). Human attitudes towards the conservation of protected areas: a case study from four protected areas in Bangladesh. Oryx, 45(3), 391-400. http://dx.doi.org/10.1017/S0030605310001067

Sekhar, N. U. (1998). Crop and livestock depredation caused by wild animals in protected areas: the case of Sariska Tiger Reserve, Rajasthan, India. Environmental Conservation, 25(2), 160-171. http://dx.doi.org/10.1017/S0376892998000204

Sifuna, N. (2005). Providing compensation for damage caused by wildlife: a case study from Kenya with particular reference to elephants. Journal of Social Development in Africa, 20, 7-39. http://dx.doi.org/10.4314\%2Fjsda.v20i1.23892

Sitati, N. W., \& Walpole, M. J. (2006). Assessing farm-based measures for mitigating human-elephant conflict in Transmara District, Kenya. Oryx, 40(3), 279-286. http://dx.doi.org/10.1017/S0030605306000834.

Sitati, N. W., Walpole, M. J., \& Leader-Williams, N. (2005). Factors affecting susceptibility of farms to crop raiding by African elephants: using a predictive model to mitigate conflict. Journal of Applied Ecology, 42(6), 1175-1182. http://dx.doi.org/10.1111/j.1365-2664.2005.01091.x

Studsrød, J. E., \& Wegge, P. (1995). Park-people relationships - the case of damage caused by park animals around the Royal Bardia National Park, Nepal. Environmental Conservation, 22, 133-142.

Sukumar, R. (1989). The Asian elephant - ecology and management. Cambridge, UK: Cambridge University Press.

Sukumar, R. (1991). The management of large mammals in relation to male strategies and conflict with people. Biological Conservation, 55(1), 93-102. http://dx.doi.org/10.1016/0006-3207(91)90007-V

Sukumar, R. (2004). The living elephants: Evolutionary ecology, behavior and conservation. New York, USA: Oxford University Press.

Tchamba, M. N. (1996). History and present status of the human elephant conflict in the Waza-Logone Region, Cameroon, West Africa. Biological Conservation, 75(1), 35-41. http://dx.doi.org/10.1016/0006-3207(95)00040-2

Tisdell, C., \& Xiang, Z. (1998). Protected areas, agricultural pests and economic damage: conflicts with elephants and pests in Yunnan, China. The Environmentalist, 18, 109-118.

Tweheyo, M., Hill, C. M., \& Obua, J. (2005). Patterns of crop raiding by primates around the Budongo Forest $\begin{array}{lllll}\text { Reserve, } & \text { Uganda. } & \text { Wildlife } & \text { Biology, } & 11(3),\end{array}$ http://dx.doi.org/10.2981/0909-6396(2005)11[237:POCRBP]2.0.CO;2 
Warren, Y., Buba, B., \& Ross, C. (2007). Patterns of crop-raiding by wild and domestic animals near Gashaka Gumti National Park, Nigeria. International Journal of Pest Management, 53(3), $207-216$. http://dx.doi.org/10.1080/09670870701288124

Weber, A. D., Hill, C. M., \& Reynolds, V. (2007). Assessing the failure of a community-based human-wildlife conflict mitigation project in Budongo Forest Reserve, Uganda. Oryx, 41, 177-184. http://dx.doi.org/10.1017/S0030605307001792

Weladji, R., \& Tchamba, M. (2003). Conflict between people and protected areas within the Benoue Wildlife Conservation Area, North Cameroon. Oryx, 37(1), 72-79. http://dx.doi.org/10.1017/S0030605303000140

\section{Copyrights}

Copyright for this article is retained by the author(s), with first publication rights granted to the journal.

This is an open-access article distributed under the terms and conditions of the Creative Commons Attribution license (http://creativecommons.org/licenses/by/3.0/). 